\title{
DETERMINANTS OF MUNICIPAL SOLID WASTE IN URBAN ZONE OF BAGLUNG MUNICIPALITY, NEPAL
}

\author{
Tejendra Regmi*, Manisha Ghimire, Suman Man Shrestha \\ Central Department of Environmental Science, Tribhuvan University, Nepal \\ *Corresponding author: tej.regmi2013@gmail.com
}

(Received:July 05, 2021; Revised: October 10, 2021; Accepted: December 7, 2021)

\begin{abstract}
The studies on the solid waste generation and characterization with their relationships with different determinants are limited in Nepal which helps in the implementation of the solid waste management approach. This study is focused on the quantification of the municipal solid waste (MSW) generation rate and its characterization in the Baglung Municipality, Nepal. Factors affecting MSW generation with perceptions towards the MSW management were also evaluated through household survey. The study was carried out in the month of January 2021 in four wards of urban zone in the municipality. The average waste generation rate in 188 households $(\mathrm{HHs}), 20$ institutions, and 20 commercial sites were $0.43 \mathrm{~kg} / \mathrm{c} / \mathrm{d}, 0.83 \mathrm{~kg} /$ institute/day and $2.75 \mathrm{~kg} / \mathrm{commercial} \mathrm{site/day,}$ respectively. The largest component, which accounted for about $74 \%$ household waste, $75 \%$ institutional waste and $52 \%$ commercial waste composed of organic waste. The analysis of variance (ANOVA) indicates a significant variation in between MSW generation rate with respect to household size and type of days. Regarding affordability of MSW management, most of the households can be able to afford service fee ranged from US\$ 0.5 to 1.0 $(55.38 \%)$. Most of the households dispose of solid waste in the municipal vehicle. From this study, the residents of the municipality are suggested to prepare compost manure at the source for the minimization of waste volume to be transported and disposed of. Higher production of recyclable MSW depicts there is a possibility of revenue generation and importance of MSW management in community mobilization in the municipality.
\end{abstract}

Keywords: Determinants, generation rate, municipal solid waste, waste characterization

\section{INTRODUCTION}

The generation rate of municipal solid waste (MSW) is increasing with the increase in the population (Moghaddam et al., 2014). The environmental problem that arises due to solid waste is considered as a crucial and emerging one (Baderna et al., 2011). Waste generation is an important element of human life and attributed to the material or object used and finally discarded as waste (Adogame, 2009). The percentage of components of waste varies in various factors, which directly depend on socio-economic components and land use type such as built-up areas and the lifestyle of the consumers (Abumere, 1983). The rate of generation and the characteristics of MSW varies spatially and temporally with the differentiation in the consumer viewpoint, rate of population growth, types of seasons and the latest available technologies in use of materials or objects (Amori et al., 2013).

The characterization of municipal household waste comprises the evaluation of MSW determinants which is considered as the foremost step to be determined for the planning and implementation of management facility of MSW (Asnani \& Zurbrugg, 2007). In the present time, more failure in the MSW management, especially in disposal techniques with no segregation in the collection phase, leads to the inappropriate characterization of wastes with an insufficient understanding of their use (Afon, 2003). The fundamental concept of solid waste management (SWM) in a city requires framework that need to be allotted locally (Ogunbiyi, 2001). Though the generation rate of MSW was estimated separately in case of Berlin (Germany), it is closely related to the features of waste, which have a direct dependence on the source types (Darmastuti, 2010).

Globally, MSW is taken as a rising issue, especially in cities of developing countries. Moreover, the rate of urban growth is rising rapidly in the time period between 2002 to 2012 and population growth rate and waste generation rate was increased by $3.5 \%$ and $87.5 \%$, respectively which accounts for more growth mainly in the developing countries (Hoornweg \& Bhada-Tata, 2012). The study conducted by Dhokhikah and Trihadiningrum, (2012) has also reported the variation in the characteristics of the MSW with respect to people's income in the settlement areas. The fraction of biodegradable waste composition in low-income countries was higher than in the high-income ones but in aggregate, the share of decomposable waste is higher in developed countries (Hoornweg \& Bhada-Tata, 2012). For instance, the fraction of biodegradable waste in East Asia and Pacific (EAP) countries is 62\% than the Organization for Economic Co-operation and Development (OECD) countries with only 27\% 
(Hoornweg \& Bhada-Tata, 2012). The studies conducted in the different countries has indicated higher organic content MSW in Casstell'on de la plana/Spain- 57\% (Bovea et al., 2010), in Portugal$35.5 \%$ (Magrinho et al., 2006) and in Bangkok/Thailand- 43\% (Chiemchaisri et al., 2007).

Various factors such as the consumer habits, the living standard of residents, the lifestyle and the types of activities in the commercial markets determine MSW generation. The seasons may also and temporally determine MSW generation (Zhu et al., 2008). This type of correlation of variables with the generation rate of MSW has the application in of waste management approaches such as collection and disposal (Al-Khatib et al., 2009). The quantification and characteristics of MSW generation denote the present state of MSW and are always indispensable to determine before the decision making in the MSW recovery and its effective management (Adeniran et al., 2017).

In the context of Nepal, a low-income country with inhabitants of 26.5 million people and an average growth rate of $1.35 \%$ (CBS, 2014), the increase in the MSW is related to the population growth in the cities
(SWMRMC, 2008). Moreover, increased MSW is also associated with the increase in the gross domestic product (GDP) which has increased from US\$ 9.04 to 21.14 billion (2006-2016) (Aleluia \& Ferrão, 2016). Limited studies have been carried out in the municipalities and rural municipalities of Nepal, regarding the SWM system.

This study examines households' socioeconomic factors that are impacting the generation of waste which play an important role in the reflection of waste quantity and characteristics. Additionally, this research also focused on the theoretical source for MSW management for the urban and suburban areas.

\section{Study area}

This study was carried out in the Baglung Municipality (Fig. 1) in Baglung District, Nepal. It has an area of 98.9 $\mathrm{km}^{2}$. It is divided into 14 wards, and has a population of 57,823 (CBS, 2011). It has a population density of 585 persons $/ \mathrm{km}^{2}$ with the average household size of 3.9. The study was conducted in four wards $(1,2,3$ and 4) in the municipality with 1082, 2111, 2610 and 832 households, respectively.

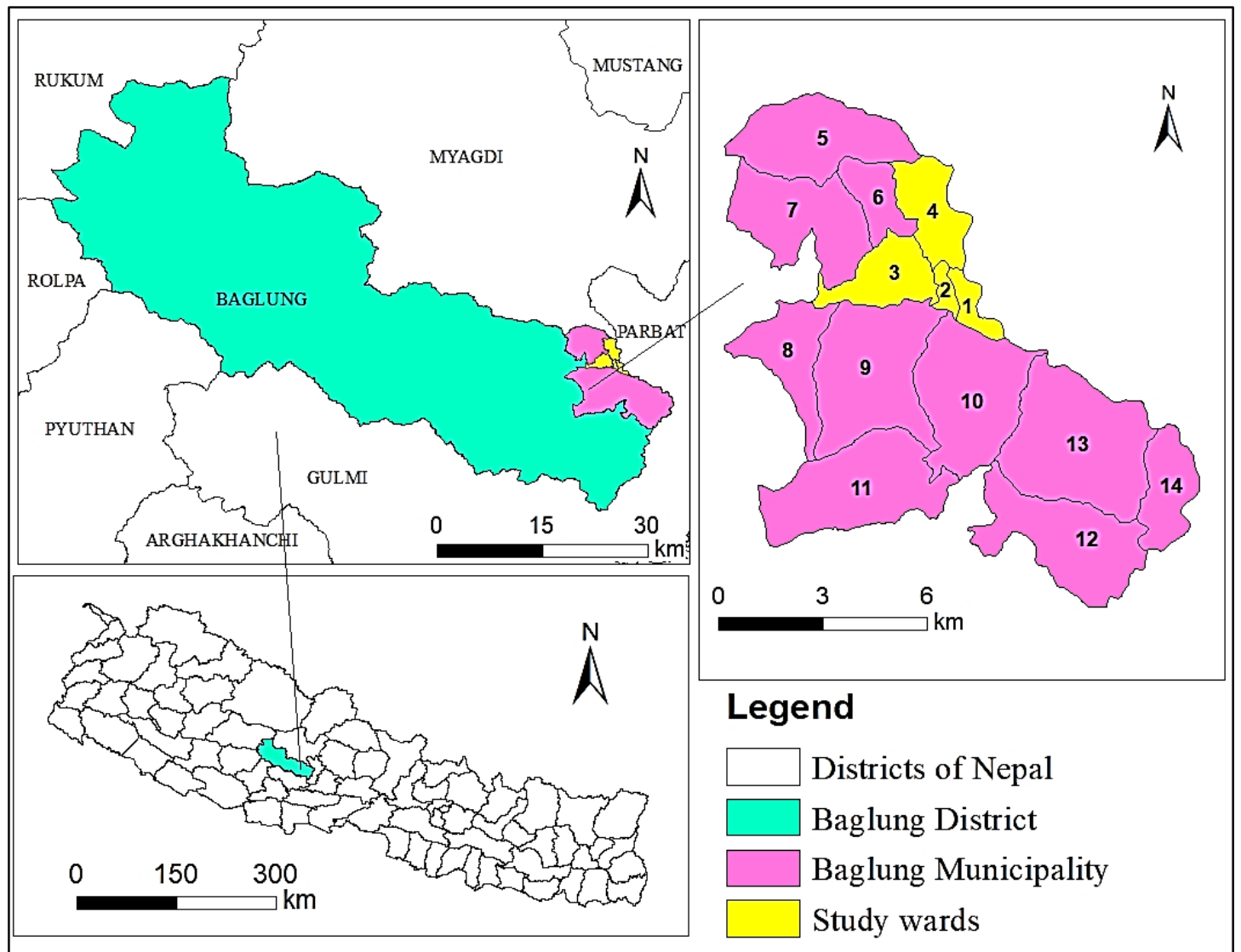

Figure 1. Map of the study area (Baglung Municipality). Numbers indicate fourteen wards of Baglung Municipality, and the yellow highlighted wards are the focal study areas. 


\section{MATERIALS AND METHODS}

\section{Household survey}

The samples of the MSW from the estimated 118 households were collected from selected four wards. Urban areas of the wards were chosen for the study. Easy road access and densely populated area were other characteristics of the selected wards. Purposive sampling was deployed for the sampling. The household survey was organized from $10^{\text {th }}$ to $22^{\text {nd }}$ of January 2021. Samplings were carried out in seven consecutive days to study the MSW generation rate and its composition. The sampling technique for the determination of the sample size was used according to Yamane (1967) at a 95\% confidence level.

$$
\mathrm{n}=\frac{\mathrm{N}}{\{1+\mathrm{N}(\mathrm{e}) 2\}}
$$

where:

$$
\begin{aligned}
& \text { n: Sample size } \\
& \text { N: Population size } \\
& \text { e: Level of precision }
\end{aligned}
$$

The estimated total number of samples were 539.01 and the final samples taken into the study were 118, which is $10 \%$ of estimated total number of samples.

\section{Institutional waste and commercial waste}

Twenty samples of institutional and commercial waste of each were also analyzed which include institutions like schools, government and non-governmental institutions and commercial places such as: shops, hotels, and restaurants. Different categories of the MSW generated in Baglung Municipality was separately assessed on the basis of the descriptions below, and their composition was determined according to the quantity contained in the bulk. The analysis of institutional and commercial waste was accomplished with aid of the household survey.

The description of waste components under each category as described by Mbeng et al. (2012) which is given as:

1. Organic: kitchen waste including vegetable and fruit peeling, wasted food

2. Plastic/Polythene: polythene bags water bottles, toys, beverage bottles

3. Paper/cardboard: newspaper, study books, copy, cardboard

4. Glass and Ceramics: beverage bottles, medicinal bottles

5. Others: old clothes, slippers, shoes, belt

\section{Sampling procedure}

The household wastes were segregated as biodegradable and non-biodegradable and were collected in the separate containers. The sample collected in the first day was not considered since the waste was not confirmed as of last 24 hours. The waste was further segregated into sub-category and weighed by using digital spring balance. Protection equipment's such as gloves and mask were used during the sampling. A semi-structured questionnaire was prepared for the collection of information about socio-economic aspect, perspective, behavior, and affordability regarding the MSW and its management. The survey was conducted with the purposive selection of the house and was shifted to the next one if the selected household was not interested in the sampling. A door-to-door interview was carried out with head of the house or the adult member of the house.

\section{Data analysis}

Microsoft Excel-2010 and Statistical Package for the Social Science (SPSS)- version 20.0 were used to analyze the data. The obtained datasets were subjected to the normality test which showed approximately normal distribution. So, the analysis was done through descriptive statistics and analysis of variance (ANOVA) test (Tabachnick \& Fidell, 2007).

\section{RESULTS AND DISCUSSION Socio-economic characteristics of surveyed households}

Overall socio-economic characteristics of respondents and respective households are presented in Table 1. Overall socio-economic characteristics of respondents and respective households are presented in Table 1. Out of the 118 households interviewed in the studied wards of Baglung Municipality, 67.8\% respondents were male. Most of the respondents have a bachelor's degree and above level of education (36.8\%) and only $3.2 \%$ of the respondents were literate. Moreover, respondents who are illiterate, with primary, secondary and higher secondary level of education were $26.4 \%$, $4.0 \%, 4.0 \%$ and $25.6 \%$, respectively. The average household size was found to be 4.61 persons with $4 \leq 5$ member's family constitute highest $(64.41 \%)$ and above 5 members constitute lowest $(14.41 \%)$. With regard to monthly income, $21.19 \%$ of the respondents earned less than 125 US\$ and 40.68\% earned between 125 and 250 US\$. Likewise, $33.05 \%$ of the respondents' income level was in between 250 and 420 US\$ and only 5.08\% have more than 420 US\$.

\section{MSW generation rate}

MSW samples from 118 households, consisting of 544 population were taken into the study. Overall, 1512.11 $\mathrm{kg}$ MSW was accumulated and segregated in the studied wards. The per capita MSW by a household is determined as $0.43 \pm 0.22 \mathrm{~kg} / \mathrm{c} / \mathrm{d}$ with 4.63 average household size. The minimum and maximum MSW generated are 0.757 and $0.239 \mathrm{~kg} / \mathrm{c} / \mathrm{d}$, respectively which reflect the significant variation in the MSW generation. The result signified the obtained data are highly skewed (skewness $>1$ ). The obtained value of 
kurtosis $>3$ which showed distribution as leptokurtic in nature. Table 2 represents the comparison of MSW generation rate in the Baglung Municipality and other cities in the world. For instance, Gorkha (Maskey \& Singh, 2017), Risikesh (Rawat \& Daverey, 2018), Suzhou (Zhang et al., 2018) and Cape Haitian City (Philippe \& Culot, 2009) have lower rate of waste generation whereas Takoradi (Miezah et al., 2015) and Mexicali City (Gomez et al., 2008) have higher household waste generation in comparison with this study. The household's generation rate of MSW is very high in Mexicali City $(0.676 \mathrm{~kg} / \mathrm{c} / \mathrm{d})$, which is a relatively developed city. Though Baglung Municipality is expanding, the generation rate is greater than other developed cities. This could be due to the difference in the study time, sample observed and variation in the season. On the other hand, the inclusion of all types of biodegradable waste generated from the households could be a reason for the elevated generation rate. The SWM baseline survey conducted in 58 municipalities of Nepal by ADB (2013) has reported the average household per capita generation of MSW was 0.17 $\mathrm{kg} / \mathrm{c} / \mathrm{d}$ which seems to be lower than the present study.

Table 1. Socio-economic characteristics of responding household.

\begin{tabular}{|c|c|c|}
\hline & Frequency & percentage $(\%)$ \\
\hline \multicolumn{3}{|c|}{ Gender of respondent } \\
\hline Male & 80 & 67.80 \\
\hline Female & 38 & 32.20 \\
\hline \multicolumn{3}{|l|}{ Age of respondent } \\
\hline $18-30$ & 12 & 10.17 \\
\hline $31-50$ & 39 & 33.05 \\
\hline $51-75$ & 54 & 45.76 \\
\hline Above 75 & 13 & 11.02 \\
\hline \multicolumn{3}{|c|}{ Family size (individuals) } \\
\hline$\leq 3$ & 25 & 21.19 \\
\hline $4 \leq 5$ & 76 & 64.41 \\
\hline$>5$ & 17 & 14.41 \\
\hline \multicolumn{3}{|c|}{ Education level of respondent } \\
\hline Illiterate & 5 & 4.00 \\
\hline Can only Read/write & 4 & 3.20 \\
\hline Primary & 5 & 4.00 \\
\hline Secondary & 32 & 25.60 \\
\hline Higher Secondary & 33 & 26.40 \\
\hline Bachelor and above & 39 & 31.20 \\
\hline \multicolumn{3}{|c|}{ Monthly income (in US\$) of respondent } \\
\hline$<125$ & 25 & 21.19 \\
\hline $125-250$ & 48 & 40.68 \\
\hline $250-420$ & 39 & 33.05 \\
\hline$>420$ & 6 & 5.08 \\
\hline
\end{tabular}

The average MSW generated is estimated as 0.83 $\mathrm{kg} /$ institute/day. The study reveals organic wastes as the largest proportion in MSW followed by paper/cardboard and plastic/polythene in the institution. Shops, hotels, and restaurants were included for the determination of waste generation rate from commercial sites and the rate vary according to their type and visited customers. MSW generation in commercial places were mostly organic $(52.43 \%$,), glass/ceramics $(26.09 \%)$ and plastic $(13.68 \%)$. The average MSW generation from commercial site is assessed as $2.75 \mathrm{~kg} /$ commercial site/day. 
Table 2. Waste generation rate in different cities in the world.

\begin{tabular}{lcl}
\hline City (Country) & $\begin{array}{c}\text { Household waste } \\
\text { generation } \mathbf{( k g / c / d )}\end{array}$ & References \\
\hline Baglung (Nepal) & 0.43 & This study \\
Bhaktapur (Nepal) & 0.11 & (KC \& Karmacharya, 2012) \\
KMC (Nepal) & 0.497 & (Dangi et al., 2011) \\
Gorkha (Nepal) & 0.24 & (Maskey \& Singh, 2017) \\
Rishikesh (India) & 0.26 & (Rawat \& Daverey, 2018) \\
Beijing (China) & 0.23 & (Gu et al., 2015) \\
Suzhou (China) & 0.28 & (Zhang et al., 2018) \\
Takoradi (Ghana) & 0.47 & (Miezah et al., 2015) \\
Cape Haitian City (Haiti) & 0.21 & (Philippe \& Culot, 2009) \\
Mexicali (Mexico) & 0.676 & (Gomez et al., 2008) \\
\hline
\end{tabular}
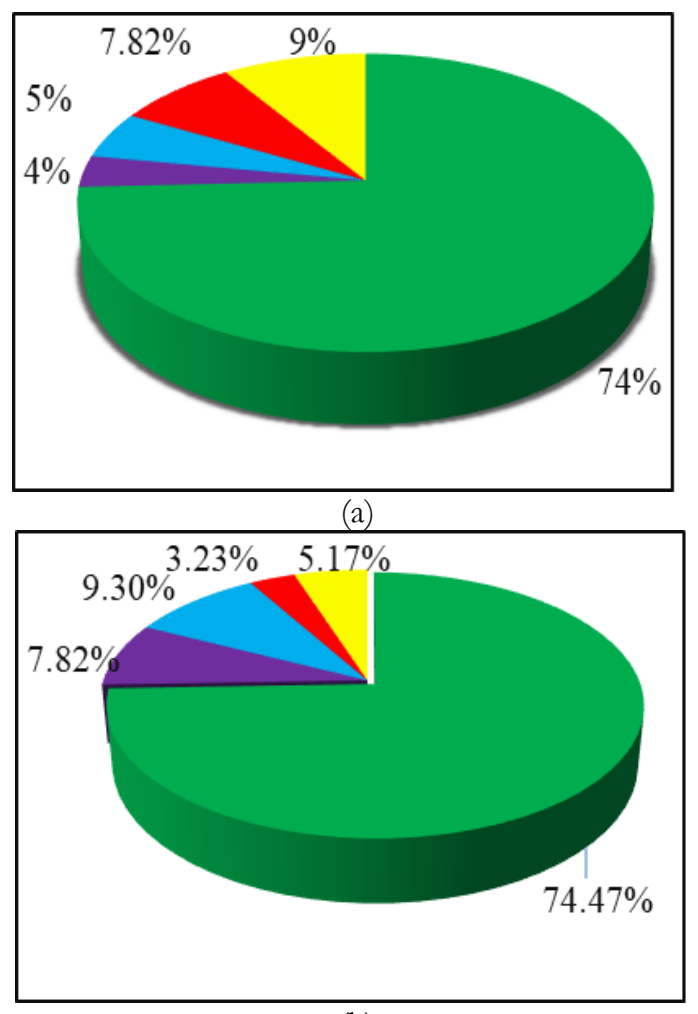

(b)

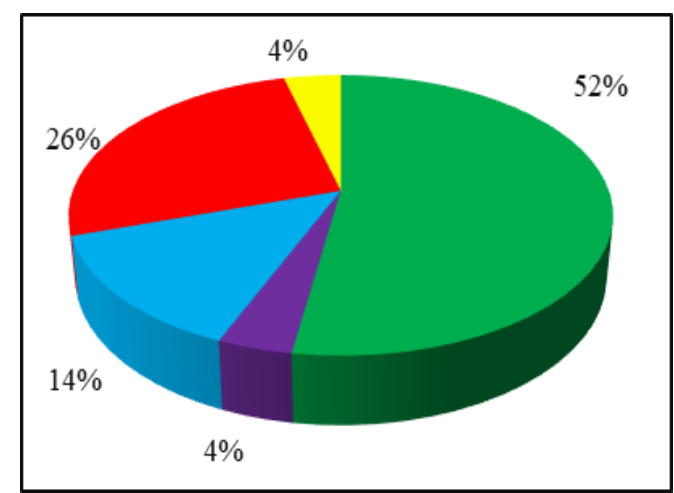

(c)

๑ Organic Waste

$\square$ Plastic/polythene

$\square$ Paper/cardboard

— Glass/ceramics

\section{Others}

Figure 2. Composition of the household waste a), institutional waste b), and commercial waste c) of Baglung Municipality.

\section{MSW characterization}

The largest component, which accounted for $74 \%$ of households waste, $74.47 \%$ of institutional waste, and $52 \%$ of commercial waste, were organic waste (Fig. 2). Similarly, the portion of glass and ceramics generated from the household and commercial waste were quite high, which was $7.82 \%$ and $26 \%$, respectively, and paper/cardboard were high $(9.30 \%)$ in institutions. The constituent of plastic/polythene in both households and institutions was $4 \%$ each whereas there was $7.82 \%$ plastic/polythene in institutional waste. Other wastes including old clothes, slippers etc. were $9 \%, 5.2 \%$, and
$4 \%$ in $\mathrm{HHs}$, institutions and commercial waste, respectively.

The composition of the MSW varies depending on the different factors such as geographical locations, climate condition, consumers' habits, lifestyle, level of nation and socio-economic condition (Iftekhar, 2005; Hoornweg \& Bhada-Tata, 2012). The composition of MSW in the study notably varied in comparison with other studies in various cities of the world (Table 3). In addition, the municipality has a higher composition of organic waste than other cities of different countries. The glass/ceramics contents in the MSW were found 
to be higher than in other cities. The quantity of plastic/polythene was recorded as higher than Asian cities like Allahabad (India) and Chittagong (Bangladesh) and lower as compared to others listed in Table 3.

\section{Factor affecting waste generation rate} household size

The number of persons in the family with less than or equal to three count 25 , four to five persons count 76 and above five persons count 17. The average MSW generation for the household size with less than or equal to three family member was $0.59 \mathrm{~kg} / \mathrm{c} / \mathrm{d}$. Ironically, households with four to five family member and more than five members account for 0.39 and 0.34 $\mathrm{kg} / \mathrm{c} / \mathrm{d}$, respectively. The frequencies of the family size of $1,2,3,4,5,6,7,8$ and 10 in the studied sample were $1,7,17,35,27,19,9,2$ and 1 households, respectively. Table 4 presents the significant variation $(\mathrm{p}<0.05)$ in the MSW generation with respect to the household size.

Table 3. Waste composition (\%) in different cities of the world compared with this study.

\begin{tabular}{|c|c|c|c|c|c|c|}
\hline City/country & $\begin{array}{l}\text { Organic } \\
\text { Waste }\end{array}$ & $\begin{array}{l}\text { Plastic/ } \\
\text { polythene }\end{array}$ & $\begin{array}{l}\text { Paper/ } \\
\text { cardboard }\end{array}$ & $\begin{array}{l}\text { Glass/ } \\
\text { ceramics }\end{array}$ & Others & Reference \\
\hline Baglung/Nepal & 74.29 & 3.44 & 5.15 & 7.82 & 9.30 & This study \\
\hline Kathmandu/Nepal & 71.0 & 12.0 & 7.5 & 1.3 & 8.4 & (Dangi et al., 2011) \\
\hline Allahabad/India & 45.3 & 2.86 & 4.69 & 0.73 & 46.42 & (Sharholy et al., 2007) \\
\hline Chittagong/Bangladesh & 62.0 & 2.0 & 3.0 & 5.0 & 12.0 & (Sujauddin et al., 2008) \\
\hline Phnom Penh/Cambodia & 63.3 & 15.5 & 6.4 & 1.2 & 13.6 & (Seng et al., 2011) \\
\hline Bangkok/Thailand & 43.0 & 10.9 & 12.1 & 6.6 & 27.4 & (Chiemchaisri et al., 2007) \\
\hline Bahrain/Bahrain Kingdom & 59.6 & 13.4 & 9.9 & 5.5 & 12.6 & (Al Sabbagh et al., 2012) \\
\hline Baghdad/Iraq & 70.0 & 5.3 & 5.0 & 2.2 & 17.5 & (Mustafa et al., 2018) \\
\hline Lagos/Nigeria & 68.0 & 7.0 & 10.0 & 4.0 & 11.0 & (Kofoworola, 2007) \\
\hline Ghana & 61.0 & 14.0 & 5.0 & 3.0 & 17.0 & (Miezah et al., 2015) \\
\hline Portugal & 35.5 & 11.5 & 25.9 & 5.4 & 21.7 & (Magrinho et al., 2006) \\
\hline Casstell'on de la plana/Spain & 57.0 & 10.0 & 15.0 & 7.0 & 11.0 & (Bovea et al., 2010) \\
\hline Chihuahua/Mexico & 48.0 & 11.9 & 16.1 & 5.9 & 18.4 & (Gomez et al., 2008) \\
\hline
\end{tabular}

Table 4. Households waste generation rate on the basis of family size.

\begin{tabular}{|c|c|c|c|c|c|c|}
\hline Groups (Family size) & \multicolumn{2}{|l|}{ Count } & $\%$ & Sum & Average $(\mathrm{kg} / \mathrm{c} / \mathrm{d})$ & Variance \\
\hline$\leq 3$ & \multicolumn{2}{|l|}{25} & 21.19 & 14.9 & 0.59 & 0.093 \\
\hline $4 \leq 5$ & \multicolumn{2}{|l|}{76} & 64.41 & 25.9 & 0.39 & 0.027 \\
\hline$>5$ & \multicolumn{2}{|l|}{17} & 14.41 & 5.8 & 0.34 & 0.018 \\
\hline \multicolumn{7}{|l|}{ ANOVA Table } \\
\hline Source of Variation & SS & df & MS & $\mathbf{F}$ & P-value & F crit \\
\hline Between Groups & 0.89 & 2 & 0.44 & 11.24605709 & $3.46061 \mathrm{E}-05$ & 3.075144 \\
\hline Within Groups & 4.56 & 115 & 0.039 & & & \\
\hline Total & 5.45 & 117 & & & & \\
\hline
\end{tabular}

The outcome of the study shows the MSW generation rate is higher in the household size of less than or equal to 3 people, whereas the rate of MSW generation rate was significantly lower with the increase in the household size. A similar result was observed in the study conducted in Rishikesh (India) by Rawat and Daverey (2018) in which the quantity of MSW was reported $0.37 \pm 0.07 \mathrm{~kg} / \mathrm{c} / \mathrm{d}$ in $\mathrm{HHs}$ size of 2 and 0.19 $\pm 0.03 \mathrm{~kg} / \mathrm{c} / \mathrm{d}$ for 8 household sizes. This reveals the lifestyle of South Asian households with the combined 
kitchen in a family. Gu et al. (2015), Ojeda-Benítez et al. (2008) and Thanh et al. (2010) also indicated identical association of rate of MSW generated with household size.

\section{Weekdays and weekends}

For this study, variation in MSW generation has been seen with respect to type of days (Sunday to Saturday) within the study period. The highest MSW recorded was on Sunday (15.11\%), commercial waste on Friday $(17.09 \%)$ and institutional waste on Sunday (19.06\%). No samples were recorded from institutional sites on Saturday (weekend). There are six weekdays (Sunday to Friday) as working days in Nepal. The effects of each day of the week (Sunday to Saturday) are presented in Table 5 .
Table 5 illustrates there is significant variation in MSW generation rate in weekdays and weekend $(\mathrm{p}<0.05)$. The MSW generation from the households is higher on Tuesday $(4.39 \mathrm{~kg} / \mathrm{h} / \mathrm{d})$, and the least on Friday (1.63 $\mathrm{kg} / \mathrm{h} / \mathrm{d})$. In Nepal, people usually purchase goods on weekends or holidays. It is presumed that the generation of MSW is higher on Saturday due to the shopping and other activities that increase the waste production. Interestingly, the accumulation of the waste is more on Tuesday. But it is noteworthy that there is the variation in the outcomes of household MSW generation from the study conducted by in the Zhu et al. (2008) in which there is maximum MSW accumulated in the weekends (Saturday- Sunday) with respect to weekdays (Monday-Friday).

Table 5. Households waste generation rate on the basis of days.

\begin{tabular}{|c|c|c|c|c|c|c|}
\hline $\begin{array}{c}\text { Groups } \\
\text { (Days) }\end{array}$ & Count & Total (kg) & $\%$ & $\begin{array}{c}\text { Average } \\
(\mathrm{kg} / \mathrm{h} / \mathrm{d})\end{array}$ & Variance & \\
\hline Sunday & 118 & 228.48 & 12.62 & 1.93 & 0.82 & \\
\hline Monday & 118 & 212.94 & 11.76 & 1.80 & 0.84 & \\
\hline Tuesday & 118 & 519.17 & 28.68 & 4.39 & 20.80 & \\
\hline Wednesday & 118 & 221.17 & 12.22 & 1.87 & 0.98 & \\
\hline Thursday & 118 & 208.89 & 11.54 & 1.77 & 0.93 & \\
\hline Friday & 118 & 192.7 & 10.64 & 1.63 & 0.79 & \\
\hline Saturday & 118 & 227.18 & 12.55 & 1.92 & 0.97 & \\
\hline \multicolumn{7}{|l|}{ ANOVA Table } \\
\hline Source of Variation & SS & df & MS & $\mathbf{F}$ & P-value & $F$ crit \\
\hline Between Groups & 678.73 & 6 & 113.12 & 30.27465 & $6.74 \mathrm{E}-33$ & 2.109633 \\
\hline Within Groups & 3060.23 & 819 & 3.73 & & & \\
\hline Total & 3738.97 & 825 & & & & \\
\hline
\end{tabular}

\section{Attitude towards MSW management}

Regarding affordability for waste collection service charge, the maximum respondents would be able to pay about US\$ 0.5 to $1.0(55.4 \%)$ and US\$ 1.0 to 1.5 $(12.3 \%)$ and less than US\$ $0.5(12.3 \%)$ per month, whilst $20.0 \%$ wouldn't be able to afford the charge and they recommended that waste generated in the municipality should be managed by the municipality office. With respect to the distance that they would travel for the MSW disposal site, about $55 \%$ of the respondents indicated that they would be able to travel 10-20 $\mathrm{m}$ distance. Most of the respondents expressed the optimistic behavior in SWM and 38.14\% of respondents proclaimed they would be able to segregate the household MSW in different subcategories: paper/cardboard, glass/ceramics, metal, plastics/ polythene, and organic waste and $12.71 \%$ of respondents showed willingness if the funds were available (Fig. 3). In contrary, $33 \%$ of respondents expressed lack of space $(8.47 \%)$, lack of time $(24.58 \%)$, afraid of diseases $(3.39 \%)$, and responsibility of the municipality $(12.71 \%)$ in MSW management.

The disposal behavior of the respondents (Fig. 4) was categorized on the basis of waste types. For organic waste, most of the respondents use the municipal vehicle for the disposal (33.0\%) while 33.0\% use to feed animals, $14.4 \%$ dispose of in the pit and remaining $19.5 \%$ make manure. Regarding non-biodegradable waste, $73.7 \%$ of the respondents use the municipal vehicles, $20.3 \%$ burn the waste and $5.9 \%$ dispose of in the pit. The common problems of SWM from the household is plastic waste $(80.0 \%)$ and the lack of the proper disposal site $(20.0 \%)$. Moreover, the common difficulties were lack of dustbins on the roadside, insufficient knowledge and technology, lack of awareness and lack of effective programs regarding SWM. 


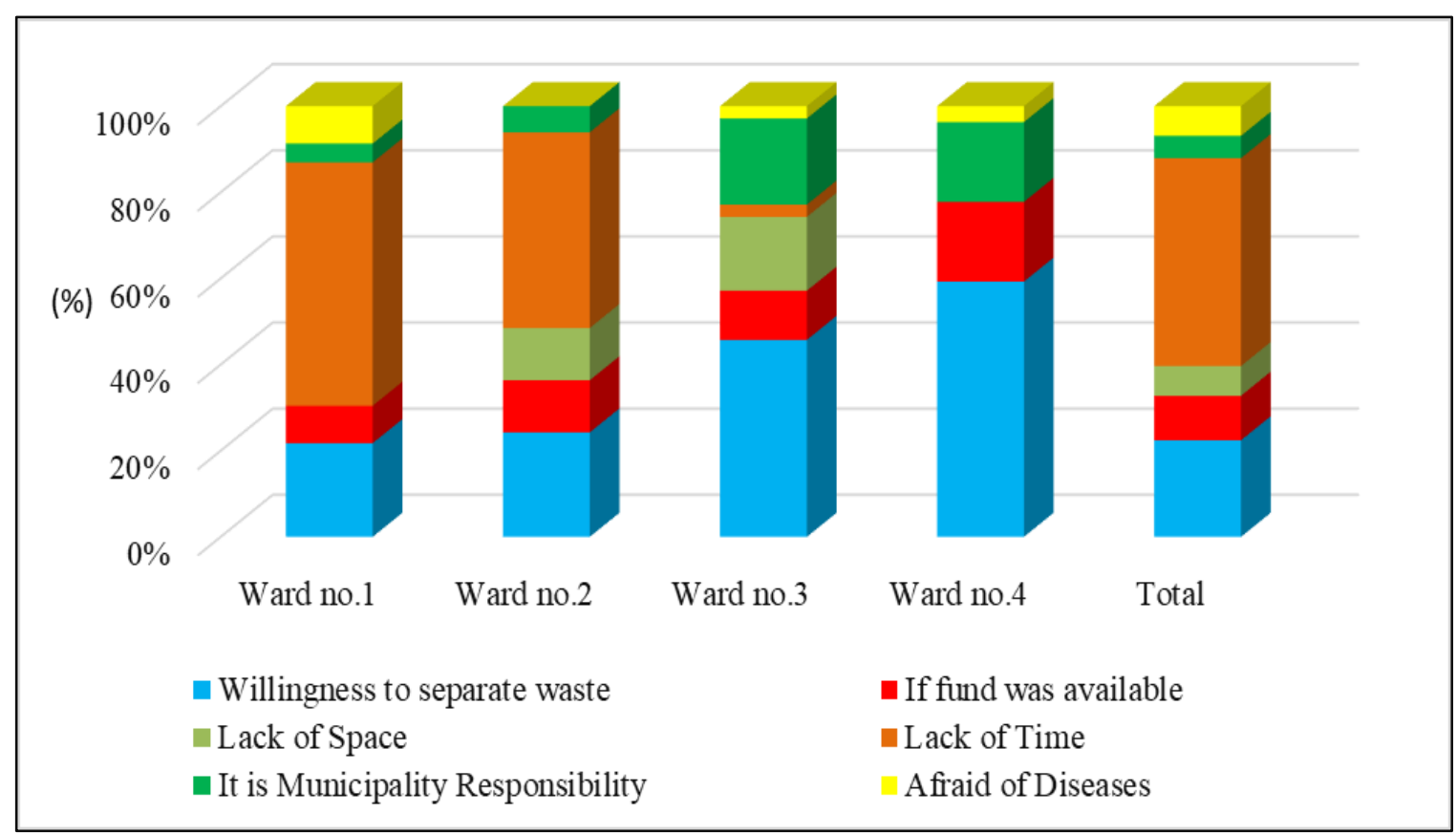

Figure 3. Responses towards the waste management in Baglung Municipality.

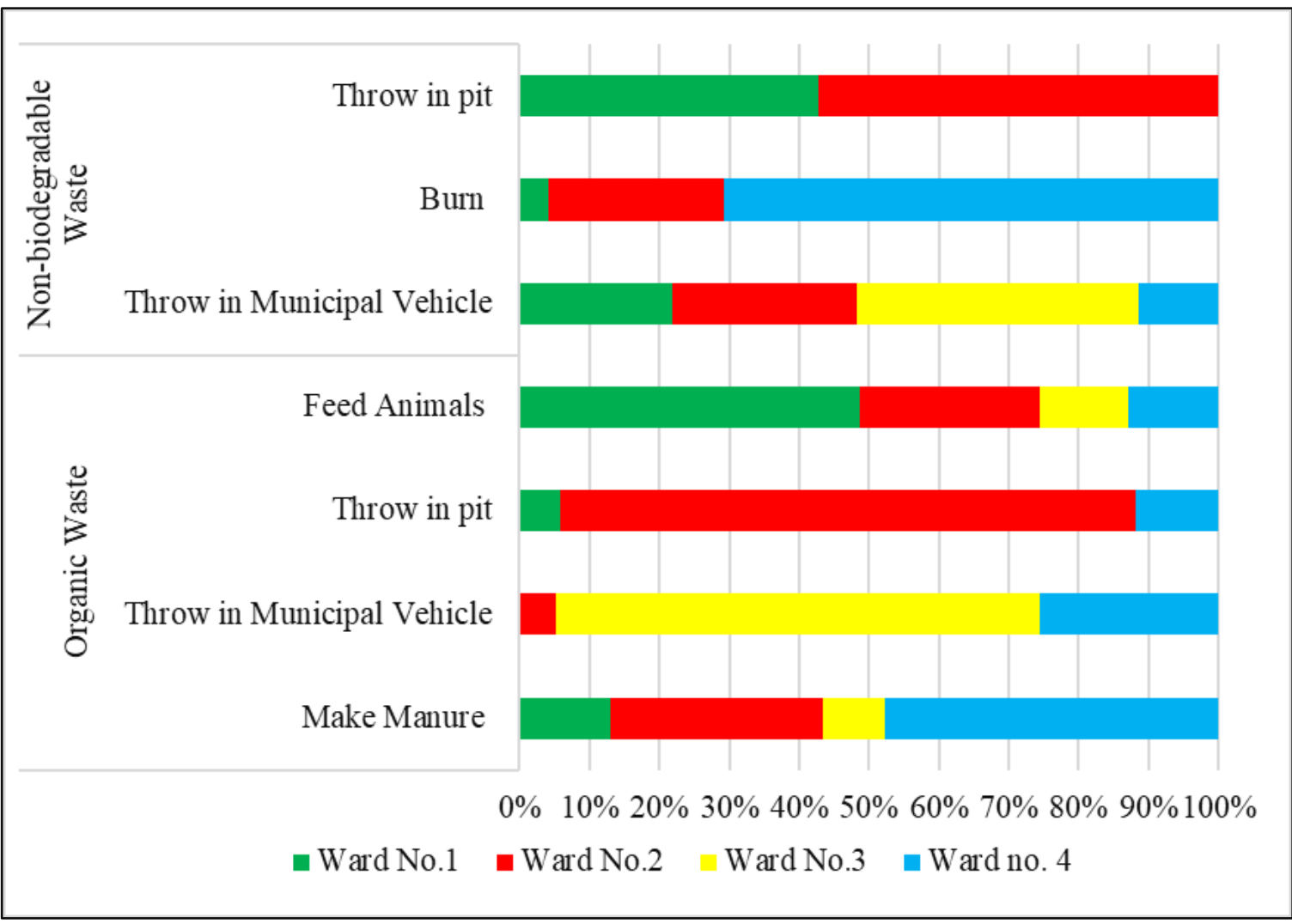

Figure 4. Disposal behavior of respondents in Baglung Municipality. 


\section{CONCLUSIONS}

The average MSW generation rates from the households, institutions and commercial sites in the Baglung Municipality were $0.43 \mathrm{~kg} / \mathrm{c} / \mathrm{d}, 0.83$ $\mathrm{kg} /$ institute/day and $2.75 \mathrm{~kg} /$ commercial site/day, respectively. $74.0 \%$ of the household waste, $74.5 \%$ of institutional waste and $52.0 \%$ of commercial waste were composed of organic waste. Similarly, 7.8\% glass/ceramics were generated from the household waste and $26.0 \%$ from commercial wastes. There was $9.3 \%$ of paper/cardboard in the institutional waste. A significant variation in between MSW generation rate with respect to household size and type of days were observed. From this study, the residents of the municipality are suggested to carry out compost manure preparation at the source, which assist in reducing volume of MSW to be transported and disposed of. Higher production of paper/cardboard and glass/ceramics could be the opportunity for the municipality to generate revenue. The local government is recommended to initiate community mobilization in the municipality for the SWM.

\section{ACKNOWLEDGEMENTS}

We sincerely thank the Central Department of Environmental Science, Tribhuvan University, Nepal. We are equally grateful to Enhancing Green Economy in 3 countries in Asia (EGEA) program for a financial support. We also thank the Baglung Municipality for the permission to carry out this study.

\section{AUTHOR CONTRIBUTIONS}

TR conceived and designed the study, reviewed outputs, defined key conclusion, contributed to key inputs, and drafted the manuscript. MG actively participated in the field work and revised the manuscript. SMS supervised, reviewed, and edited the work in all phases.

\section{CONFLICT OF INTEREST}

The authors declare no competing interests.

\section{DATA AVAILABILITY STATEMENT}

The data that support the findings of this study are available from the corresponding author, upon reasonable request.

\section{REFERENCES}

Abumere, S.I. (1983). City surface solid waste in Nigerian cities. Environment International, 9(5), 391-396.

ADB. (2013). Solid waste management in Nepal; current status and policy recommendations. Metro Manila, Philippines: Asian Development Bank.

Adeniran, A.E., Nubi, A.T., \& Adelopo, A.O. (2017). Solid waste generation and characterization in the University of Lagos for a sustainable waste management. $W$ aste Management, 67, 3-10.
Adogame, L. (2009). Toward Enhanced Public-Private Partnership in Solid Waste Management in Lagos State. Effective solid waste management, Lagos Airport Hotel, Ikeja, Nigeria, August.

Afon, A.O. (2007). Informal sector initiative in the primary sub-system of urban solid waste management in Lagos, Nigeria. Habitat International, 31(2), 193-204.

Aleluia, J., \& Ferrão, P. (2016). Characterization of urban waste management practices in developing Asian countries: A new analytical framework based on waste characteristics and urban dimension. Waste Management, 58, 415-429.

Al-Khatib, I.A., Arafat, H.A., Daoud, R., \& Shwahneh, H. (2009). Enhanced solid waste management by understanding the effects of gender, income, marital status, and religious convictions on attitudes and practices related to street littering in Nablus-Palestinian territory. W aste Management, 29(1), 449-455.

Al-Sabbagh, M.K., Velis, C.A., Wilson, D.C., \& Cheeseman, C.R. (2012). Resource management performance in Bahrain: a systematic analysis of municipal waste management, secondary material flows and organizational aspects. Waste Management \& Research, 30(8), 813-824.

Amori, A.A., Fatile, B.O., Ihuoma, S.O., \& Omoregbee, H.O. (2013). Waste generation and management practices in residential areas of Nigerian tertiary institutions. Journal of Educational and Social Research, 3(4), 45.

Asnani, P.U., \& Zurbrugg, C. (2007). Improving municipal solid waste management in India: A sourcebook for policymakers and practitioners. World Bank Publications.

Baderna, D., Maggioni, S., Boriani, E., Gemma, S., Molteni, M., Lombardo, A., Colombo, A., Bordonali, S., Rotella, G., Lodi, M., \& Benfenati, E. (2011). A combined approach to investigate the toxicity of an industrial landfill's leachate: chemical analyses, risk assessment and in vitro assays. Environmental Research, 111(4), 603-613.

Bovea, M.D., Ibáñez-Forés, V., Gallardo, A., \& ColomerMendoza, F.J. (2010). Environmental assessment of alternative municipal solid waste management strategies. A Spanish case study. Waste Management, 30(11), 23832395.

CBS. (2011). Nepal living standards survey 2010/ 2011. Kathmandu, Nepal: Central Bureau of Statistics.

CBS. (2014). National population and housing census 2011 (Village development committee/municipality) (Vol. 6). Kathmandu, Nepal: Central Bureau of Statistics.

Chiemchaisri, C., Juanga, J.P., \& Visvanathan, C. (2007). Municipal solid waste management in Thailand and disposal emission inventory. Environmental Monitoring and Assessment, 135(1), 13-20.

Dangi, M.B., Pretz, C.R., Urynowicz, M.A., Gerow, K.G., \& Reddy, J.M. (2011). Municipal solid waste generation in Kathmandu, Nepal. Journal of Environmental Management, 92(1), 240-249.

Darmastuti, Z., Handayani, I., \& Irving, M. (2010). Life Cycle Analysis of Green House Gas Emissions from Biogas Compared to Alternative Energy Sources. Selected papers proceeding-Energy Conference (12-13), Berlin, Germany.

Dhokhikah, Y., \& Trihadiningrum, Y. (2012). Solid waste management in Asian developing countries: challenges and opportunities. Journal of Applied Environmental and Biological Sciences, 2(7), 329-335. 
Gomez, G., Meneses, M., Ballinas, L., \& Castells, F. (2008). Characterization of urban solid waste in Chihuahua, Mexico. Waste Management, 28(12), 2465-2471.

Gu, B., Wang, H., Chen, Z., Jiang, S., Zhu, W., Liu, M., Chen, Y., Wu, Y., He, S., Cheng, R., Yang, J., \& Bi, J. (2015). Characterization, quantification and management of household solid waste: A case study in China. Resources, Conservation and Recycling, 98, 67-75.

Hoornweg, D., \& Bhada-Tata, P. (2012). What a Waste: A Global Review of Solid Waste Management. Urban development series; knowledge papers no. 15. World Bank, Washington, $D C$.

Iftekhar, E.A.H., Maqsood, M., \& Khan, S.A. (2005). A Report on Urban Solid Waste Management Scenario of Bangladesh; Problems and Prospects. Waste Concern Publications, Dhaka, Bangladesh.

KC, U., \& Karmacharya, S. (2012). Report of Solid Waste Management Baseline Study in Bhaktapur Municipality. Solid Waste Management Technical Support Center (SWMTSC), Ministry of Local Development, Kathmandu, Nepal.

Kofoworola, O.F. (2007). Recovery and recycling practices in municipal solid waste management in Lagos, Nigeria. Waste Management, 27(9), 1139-1143.

Magrinho, A., Didelet, F., \& Semiao, V. (2006). Municipal solid waste disposal in Portugal. W aste Management, 26(12), 1477-1489.

Maskey, B., \& Singh, M. (2017). Household waste generating factors and composition study for effective management in Gorkha municipality of Nepal. Journal of Sustainable Development, 10(6), 169-185.

Mbeng, L.O., Phillips, P.S., \& Fairweather, R., (2012). Waste characterisation as an element of household waste management operations: A case study in Limbe, Cameroon. Open W aste Management Journal, 5, 49-58.

Miezah, K., Obiri-Danso, K., Kádár, Z., Fei-Baffoe, B., \& Mensah, M.Y. (2015). Municipal solid waste characterization and quantification as a measure towards effective waste management in Ghana. Waste Management, 46, 15-27.

Moghaddam, T.B., Soltani, M., \& Karim, M.R. (2014). Evaluation of permanent deformation characteristics of unmodified and Polyethylene Terephthalate modified asphalt mixtures using dynamic creep test. Materials \& Design, 53, 317-324.

Mustafa, A.S., Mohsin, A.A., \& Ali, L.N. (2018). Management of Municipal Solid Waste in Baghdad, Iraq. International Journal of Environmental and Ecological Engineering, 11(7), 700 704.

NRB. (2021). Foreign Exchange Rates for Transfer Nepal Rastra Bank, Kathmandu, Nepal.
Ogunbiyi, A. (2001). Local technology in solid-waste management in Nigeria. In Proceedings of the National Engineering Conference and annual general meeting of the Nigerian Society of Engineers (pp. 73-79).

Ojeda-Benítez, S., Armijo-de Vega, C., \& MarquezMontenegro, M.Y. (2008). Household solid waste characterization by family socioeconomic profile as unit of analysis. Resources, Conservation and Recycling, 52(7), 992999.

Philippe, F., \& Culot, M. (2009). Household solid waste generation and characteristics in Cape Haitian City, Republic of Haiti. Resources, Conservation and Recycling, 54(2), 73-78.

Rawat, S., \& Daverey, A. (2018). Characterization of household solid waste and current status of municipal waste management in Rishikesh, Uttarakhand. Environmental Engineering Research,23(3), 323-329.

Seng, B., Kaneko, H., Hirayama, K., \& Katayama-Hirayama, K. (2011). Municipal solid waste management in Phnom Penh, capital city of Cambodia. Waste Management \& Research, 29(5), 491-500.

Sharholy, M., Ahmad, K., Vaishya, R.C., \& Gupta, R.D. (2007). Municipal solid waste characteristics and management in Allahabad, India. W aste Management, 27(4), 490-496.

Sujauddin, M., Huda, S.M.S., \& Hoque, A.R. (2008). Household solid waste characteristics and management in Chittagong, Bangladesh. Waste Management, 28(9), 16881695.

SWMRMC. (2008). Baseline study on solid waste management in municipalities of Nepal. Solid Waste Management and Resource Mobilization Center Kathmandu, Nepal.

Tabachnick, B.G., \& Fidell, L.S. (2007). Using multivariate statistics (5 $5^{\text {th }}$ Edition). Boston: Allyn and Bacon/Pearson Education.

Thanh, N.P., Matsui, Y., \& Fujiwara, T. (2010). Household solid waste generation and characteristic in a Mekong Delta City, Vietnam. Journal of Environmental Management, 91(11), 2307-2321.

Yamane, T. (1967). Statistics: An introductory analysis (2nd ed.). New York: Harper and Row.

Zhang, H., Duan, H., Andric, J.M., Song, M., \& Yang, B. (2018). Characterization of household food waste and strategies for its reduction: A Shenzhen City case study. W aste Management, 78, 426-433.

Zhu, D.; Asnani, P.U., Zurbrügg, C., Anapolsky, S., \& Mani, S. (2008). Improving municipal solid waste management in India: A sourcebook for policy makers and practitioners. Washington, DC: World Bank. 